\title{
RELATOS DE PROFESSORAS, ANDANÇAS DE SENTIDOS
}

\section{TEACHERS'REPORTS: WANDERINGS OF SENSES}

\section{RELATOS DE PROFESORAS, CAMBIOS DE SENTIDOS}

\author{
Mitsi Pinheiro de Lacerda* \\ Professora do Departamento de Ciências Humanas e do Programa de Pós-Graduação \\ em Ensino da Universidade Federal Fluminense \\ Annete Hosken ${ }^{* *}$ \\ Professora da Rede Pública Municipal de Carangola, Minas Gerais
}

Resumo: O artigo trata da natureza inaugural dos relatos de professoras, os quais contêm séculos de conversações. Compreendidos enquanto transportes que conduzem os sentidos postos por elas, alguns relatos são desdobrados para, em seu interior, serem encontradas algumas influências que se prendem ao pensamento. Com isso, a escuta também é afetada, implicando a reflexão epistemológica de quem ouve. $\mathrm{O}$ artigo sinaliza que, em sua superfície, a racionalidade técnica predomina em muitas narrativas docentes, e que costuma lhes ser imputada. O texto denuncia a existência não deliberada de concepções mecanicistas nas narrativas docentes. Junto às orientações certeaunianas, abandona os resquícios de um discurso formatado para, talvez, adentrar o espaço habitado pela professora.

Palavras-chave: Relatos. Racionalidade Técnica. Formação de Professoras.

Abstract: The article describes the inaugural nature of the narratives of teachers, which contain centuries of talks. Understood as transport that leads their coherence, some narratives are open and found some influences into the thought. Thus, the listening is also affect, resulting in the epistemological reflection's researcher. The article indicates

\footnotetext{
* Doutora em Educação pela Universidade de São Paulo; Licenciada em Letras pela Fundação FAFILE de Carangola.

** Mestranda em Ensino no Programa de Pós-Graduação em Ensino da Universidade Federal Fluminense; Licenciada em Pedagogia pela Universidade do Estado de Minas Gerais.
} 
that, on its surface, the technical rationality prevails in many narratives teachers, and it use to be attributed to them. The text denounces the unintended presence of mechanistic conceptions on teaching narratives. Next to Michel de Certeau, the article leaves the remains of a speech formatted to enter the space inhabited by the teacher.

Keywords: Narratives. Technical rationality. Teachers education.

Resumen: El artículo se trata de la naturaleza inaugural de los relatos de profesoras, los cuales contienen siglos de conversaciones. Comprendidos como transportes que conducen los sentidos puestos por ellas, algunos relatos son desdoblados para que, em su interior, sean encontradas algunas influencias que se aten al pensamiento. Com eso, la escucha también es afectada, provocando la reflexión epistemológica de quién escucha. El artículo muestra que, en su superficie, la racionalidade técnica predomina en muchas narrativas docentes, y que acostumbra serle imputado. El texto denuncia la existencia no deliberada de concepciones mecanistas en las narrativas docentes. Junto a las orientaciones certeaunianas, abandona los vestigios de un discurso formateado para, tal vez, penetrar en el espacio habitado por la profesora.

Palabras clave: Relatos. Racionalidad Técnica. Formación de profesoras.

\title{
1 INTRODUÇÃO
}

\author{
Para eles a história era uma estória como outra qualquer \\ repisada demais na memória. \\ [...] O tempo as marcou a ferro \\ e a ferros restaram na sala das infinitas possibilidades que \\ expulsaram. \\ Mas podem ter sido possíveis visto jamais terem sido? \\ Ou era só possível o que veio a ser? \\ Tece, tecelão do vento. \\ James Joyce
}

Cada relato é inaugural e carrega, em si, séculos de conversações. Aparentemente situados em determinados espaços e tempos, os relatos contêm influências advindas do passado e intuições do futuro, o que inscreve sua natureza histórica, política e social. A fala de uma professora é carregada de sentidos que ela mesma tece, impregnados por tantos outros que ela talvez nem suponha existir. Vulneráveis às interferências externas, os relatos reanimam as práticas docentes como se fossem outras, matizando-as com ideias e concepções que não foram, necessariamente, pensadas pela professora que as reproduz. 
A verbalização de um relato não é comprometida com a explicitação dos sentidos que o tecem. De natureza metafórica e bastante assemelhado a uma descrição, os relatos da prática requerem uma escuta densa que tome a audição tão somente como um dispositivo. Na superfície, muitas narrativas docentes sinalizam a predominância de uma racionalidade técnica cuja gênese costuma ser imputada a elas que, tão somente, consomem o que também está posto na superfície do tecido social. Pensar sobre narrativas de professoras requer, então, um mergulho além desta camada aparente, aproveitando a ocasião tanto para ouvir quanto para aprender a ouvir.

Neste artigo, trazemos histórias de escolas, narradas por professoras. O registro escrito destes relatos verbais servirá como transporte à busca de sentidos, os quais, conforme exposto, não são explícitos. Praticantes dos cotidianos (CERTEAU, 1994) sabem, muito bem sabido, que sua linguagem, conhecida como "senso comum", não é legitimada; sabedores disso, oferecem sorrateiramente seus relatos quando o impositivo do silêncio não os acolhe, e, abertamente, quando as condições se mostram ótimas neste sentido. Por não serem considerados legítimos, tais relatos circulam às escondidas das garras da regulação - já que são subestimados como "menores" e "menos". Bonito paradoxo, este: o mesmo dispositivo que classifica e deslegitima as narrativas da prática, é o que engendra as condições de possibilidades para que estas narrativas se proliferem pelo mundo.

Traremos, portanto, histórias de escolas. Junto a elas, empreenderemos uma espécie de conversação onde estarão presentes as narrativas, os sentidos que desconfiamos estarem escondidos em suas tramas, alguns amigos autores convidados e também nossas expectativas sobre nosso futuro e estimado leitor (a). É importante salientar que as narrativas foram compartilhadas por professoras em contextos de enunciação no cotidiano escolar, posteriormente registradas por escrito pelas autoras deste artigo e que sua ocorrência aconteceu por acaso ${ }^{1}$. Isso implica que estas narrativas não são fruto da execução de um procedimento planejado, mas que ocorreram desde a configuração ótima de condições diversas que se configuraram: um acontecimento, a indignação, a postura política, um encontro, a confiança que reside na amizade, a potência da palavra. Os relatos, portanto, ocorreram em espaços e tempos diferenciados, em uma mesma cidade pequena, onde a restrita dimensão territorial do lugar favorece o encontro, as conversas e achados preciosos.

O texto está dividido em três seções. Na primeira delas, trazemos a narrativa de uma professora que se queixava da "indisciplina" de seus alunos, afirmando que cada turma seria uma espécie de "massinha de modelar" entregue às manipulações docentes. Com esta narrativa, propomos-nas a pensar sobre as influências que 
articulam percepções desta natureza e, buscando auxílio na figura da bailarina, observamos a racionalidade técnica subjacente aos mecanismos que adentram os processos formativos. A seguir, entabulamos uma conversação com Michel de Certeau, de forma a compreender o trabalho dos relatos junto à tessitura do espaço praticado. Para esta conversação, convidamos a professora Alice que, aliás, não foi convidada, mas adentrou intempestivamente uma conversa que acontecia na escola, movida pela indignação suscitada por evento ocorrido neste cotidiano escolar. Neste momento, aprendemos um pouco mais sobre as demarcações espaciais da escola, e também sobre a potência da palavra da professora. Por fim, ouvimos outra professora que, em um encontro promovido pelo acaso, sinalizou em sua saudosa narrativa as regulações às quais a escola tem sido submetida na atualidade. Tudo isso conversado, são tecidas algumas breves considerações de forma a finalizar o artigo. Vamos, então, às histórias.

\section{MARCAÇÕES CORPORAIS: HERANÇAS DA FORMAÇÃO}

Como professoras, estamos frequentemente envolvidas em conversas. Encontramo-nos nos mais diversos lugares e, em meio a tantos assuntos, geralmente tecemos nossas conversas rumo ao cotidiano escolar. Depois que as conversas passam, algumas não saem de nossas cabeças, pois permanecem perturbando, intrigando, e isso talvez seja indício de que conversas não passam, mas continuam. Em continuidade a uma destas tantas conversas, trazemos o que falava uma professora sobre as turmas de estudantes, afirmando que as turmas que são formadas atualmente, nas escolas, são muito diferentes daquelas que existiam há pouco tempo. Ela dizia estar a cada dia mais negativamente impressionada com as turmas que ingressavam na escola. Segundo ela, as turmas estão cada vez piores pois têm reunido crianças mais agitadas, menos concentradas, pouco disciplinadas. Em sua fala, descreve o que observa na escola e explica que, a cada ano que passa, demora mais tempo para colocar a turma "do seu jeito". O argumento que utiliza para sustentar sua fala é de cada turma seria como uma "massinha de modelar", que a professora vai moldando, moldando, até ficar do seu jeito. Com a "sua cara".

Massinha de modelar... para esta professora, cada turma é uma massinha de modelar. Poderia ser também uma sementinha a desabrochar, uma folha de papel em branco onde vai escrever algo ou qualquer outra metáfora reducionista. A afirmativa da professora instiga a pensar sobre as concepções anunciadas em sua fala: até quando professoras insistirão em dizer ser possível moldar seus alunos para que fiquem com a “sua cara"? Será que eles algum dia realmente ficaram com a “cara de alguém”? Será 
que eles querem "mudar de cara"? Esta "cara certa" é o melhor para quem? A partir de quê? Como professoras, podemos ter nos questionado pouco sobre isto, e esta reflexão poderia começar a fazer diferença em nossa prática docente.

Ela é professora e, para ela, seus alunos são "massinha de modelar". Esta metáfora inscreve-se junto a tantas outras que, como ela, também estabelecem um observador externo que controla, classifica e analisa a realidade. Fartamente utilizadas em educação, metáforas que remetem a degraus de escadas, a tijolos de construção, a caminhos lineares, à base de edifícios e também ao inusitado da "massinha de modelar", apesar de bastante diferentes entre si, compartilham de concepções semelhantes. Estas concepções, herdadas desde um pensamento científico e de um modelo de produção têm, como princípio, o próprio "princípio" - a gênese a partir da qual tudo se dá.

Segundo esta lógica, este princípio seria uma "base" que precisaria ser fortalecida, de forma a que a consecução das etapas subsequentes pudesse ser ordenadamente direcionada. A partir destas ideias, a aprendizagem deveria ter esta base sólida sobre a qual se poderia erigir cada um dos módulos da construção, e a edificação traria, na altitude progressiva de seus degraus e nos tijolos assentados uns sobre os outros, a certeza de que aprender é algo que acontece por meio de etapas sucessivas e com graus de dificuldades crescentes. A figura do caminho reforçaria a existência de um percurso único a ser percorrido simultaneamente por todos e, na fala desta professora, a massinha de modelar poderia ser considerada a engenhosidade plástica que consolidaria a hegemonia e centralidade docente.

Esta herança moderna ainda hoje adentra o tecido social, interferindo junto à nossa cognição, direcionando nossas percepções e - naquilo que aqui nos interessa - afetando a nós, professoras. Não é possível deixar de pensar que crianças são massinhas, mas é possível "pensar este pensamento" para, assim, dissipá-lo em um movimento que inclua o olhar para nós mesmas. Por onde quer que se vá, há sempre um modelo ideal a ser seguido: um modelo de aula, um modelo de aprendizagem, um modelo de gente. As concepções modernas predispõem as professoras a cultivarem um olhar linear e uniforme, possível apenas em ambientes homogêneos e submetidos ao controle das próprias concepções que o delineiam. Quem governa sabe que a uniformização e a supressão das diferenças configura um quadro passível de ser dominado, pois, como aprendemos com Foucault, "a visibilidade é uma armadilha." (FOUCAULT, 1987, p. 166).

E já que estamos tratando de metáforas e modelos, tomemos a figura da bailarina para nos ajudar a pensar. Sem a menor pretensão por adentrar seu processo formativo, vejamos a bailarina em dois suportes distintos, o poema e a pintura. Repare 
que a figura da bailarina, aqui, não é o que nos interessa, mas dois diferentes olhares que são lançados sobre ela. Neste poema fartamente conhecido, encontramos uma menina tão pequenina e seu sonho de ser bailarina: "Esta menina/tão pequenina/quer ser bailarina/Não conhece nem dó, nem ré/Mas sabe ficar na ponta do pé." (C. Meireles, A bailarina). A leitura deste poema remete à visão de várias bailarinas, todas muito parecidas, aprendendo a partir dos mesmos exercícios mecanicistas, repetitivos, reproduzidos. Os versos dizem que ela ainda não “conhece”, mas já sabe sobre a técnica de ficar "na ponta do pé". Esta bailarina copia e cola o movimento, erra e repete o gesto... seu sonho já lhe foi entregue sonhado, seu corpo já dispõe de um projeto para ser esculpido, resta a ela se ajustar ao modelo. Mas, onde está você, bailarina?

Em nossa busca por bailarinas, encontramos outras, filhas de Degas. Nascido no ventre de uma família aristocrática no início do século XIX, Edgar Degas foi um revolucionário para a sua época. Rompeu com o Romancismo, perpassando pelo Realismo até tornar-se conhecido, mais tarde, como o fundador do Impressionismo. Pintava cenas de seu cotidiano e conseguia imprimir "movimento" às imagens. $\mathrm{O}$ enquadramento de suas figuras fugia do convencional. Ele não pintava as bailarinas no "auge" da beleza de suas apresentações, mas no toucador ou exaustas, sentadas ao chão. Ele rompe com uma forma hegemônica de se retratar a realidade (centralidade, estética, ordem) e introduz a cena a partir da expressão dos praticantes. Uma breve observação de seu trabalho revela uma obra renitente, com pinceladas certeaunianas.

Nas pinturas de Degas, os personagens retratados não estão centralizados na imagem, como seria de se esperar em uma pintura da era clássica. Grande parte de seus quadros retrata momentos da vida cotidiana com os personagens despojados, à vontade, de costas para o observador e, muitas vezes, parcialmente cortados da cena. É como se o pintor rompesse com uma vida ordenada, centralizada, e também como se dissesse: "não se mostre para mim como você precisa ser; mostre-se para mim como você pensa que é”. Em uma analogia atrevida, poderíamos dizer que, poeticamente, as bailarinas de Degas denunciariam sua humanidade, assim como posto ironicamente pelo poema:

Procurando bem

Todo mundo tem pereba

Marca de bexiga ou vacina

E tem piriri

Tem lombriga, tem ameba

Só a bailarina que não tem 
E não tem coceira

Verruga nem frieira

Nem falta de maneira ela não tem.

(E. Lobo e C. Buarque, Ciranda da Bailarina)

Na Imagem 1, reproduzimos uma das pinturas de Degas. Aqui, as bailarinas são retratadas em uma aula de balé, o que poderia gerar a expectativa da visualização de meninas executando movimentos idênticos e simultâneos. Diferente disso, o que o pintor oferece não guarda qualquer relação com esta imagem canônica. Em seu quadro, vemos as meninas pintadas em tons pastéis, característica da obra de Degas ao pintar bailarinas, e elas se encontram em uma sala onde são ensaiados passos de balé. $\mathrm{Na}$ sala, há duas janelas com leves cortinas brancas, por onde é permitida a entrada de luz, mas que não revela ao mundo o que fazem as bailarinas. Ao chão, provisoriamente esquecido de sua função, há um violoncelo desfrutando deste momento em que não lhe é exigida a repetição exaustiva dos mesmos acordes. Uma das meninas encontra-se sentada em uma cadeira, e é possível ver seus pés separados, voltados para as laterais de seu corpo, em posição de dança. Para marcar seu status de bailarinas, todas trajam vaporosas saias, prendem os cabelos em impecáveis coques e usam suas sapatilhas de cetim. Em contradição a estes marcos regulatórios, o "enquadramento" da obra revela uma marca de seu autor, a da recusa pelo "enquadramento". Não há um centro, não há uma perspectiva, não há uma estética hegemônica. A impressão é de que a tela foi pintada a partir de um dos poucos momentos de afrouxamento da técnica, pois as meninas são retratadas fora de qualquer linearidade ou ordenamento.

Imagem 1 - The dance lesson, Edgar Degas, 1879

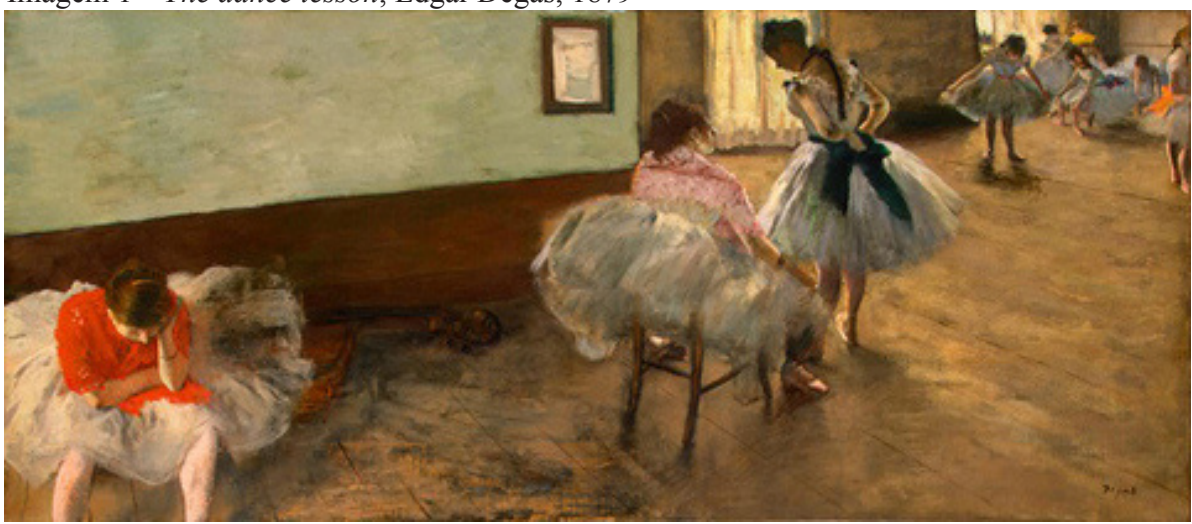

Fonte: National Gallery of Art in Washington, D.C. 
O encontro com as bailarinas de Degas nos presenteou com algumas possibilidades de conversação. As bailarinas olham para seus pés. Os pés são a parte do corpo onde as marcas de seu trabalho se depositam; eles denunciam o que fazem, a intensidade com a qual se dedicam ao que fazem e também os indícios da técnica que as configura. O corpo da bailarina fala através de seus pés. É um corpo que fala, e isso ajuda a entender que a fala não é privilégio da voz. Não parecem estar preocupadas com os passos de balé que deveriam desenvolver, nem mesmo com a leveza de seus movimentos, mas olham para seus pés. Quais significados eles têm para uma bailarina? Os pés sustentam todos os seus esforços, toda a repetitiva vida da bailarina. A disciplina de uma vida. Sustentam sua dor, a tal ponto de, ao longo de sua carreira, as bailarinas terem os pés modificados pela repetição, pela exaustão. As bailarinas de Degas parecem se entregar à pergunta que endereçam a si mesmas. Por que estão ali? Será que escolheram estar naquela condição? O que o corpo da bailarina fala neste quadro não coincide com o que este mesmo corpo revela, nas apresentações de balé ao público, pois a dor e a monotonia ficam escondidas sob a delicadeza das sapatilhas, a leveza das roupas, o equilíbrio dos movimentos, as cores suaves e a música que encanta a cena.

Curiosamente, elas olham para os próprios pés. Este detalhe foi provocativo durante a contemplação da obra de arte, e fez pensar. No corpo da bailarina, os pés denunciam, por meio de sua alteração física, o emprego da técnica, as repetições de movimentos idênticos, as tentativas de superação daquilo que se é, para aquilo que se deve ser. Talvez, por isso, as bailarinas olhem para os pés. Talvez observem, com espanto, o que o mecanicismo, posto a partir da exterioridade, produziu nelas. Valeria a pena arriscar, aqui, uma analogia com a formação de professoras? Façamos um esforço para, quem sabe, compreender aquela ideia de "crianças-massinhas-de-modelar" enquanto pés modificados por um agente externo que emprega uma intenção específica e não inclui, nesta (de)formação, a professora que pensa, e faz. Usa seu corpo (e pensamento), tão somente.

A racionalidade técnica, os pressupostos modernos, a lógica positivista, as teorias behavioristas, a política neoliberal - são tantos os fluídos reducionistas que ainda penetram os projetos formativos! De facílima apreensão e resguardados por uma suposta cientificidade, por vezes adentram sem dificuldade as práticas e se propagam por meio de narrativas. Adentram e se instalam, tornando-se mediadores de um pensar e de um fazer.

Mas... há quem olhe espantosamente para os próprios pés. Há quem consiga perceber em sua corporeidade, gestos, pensamentos e em sua voz, as marcas de sucessi- 
vas tentativas por conformá-los a uma lógica que não é a sua. Há quem consiga "pensar certo", conforme ensinou nosso querido Paulo Freire (1997); um "pensar certo" que não se confunde com um suposto pensamento único e verdadeiro, mas um pensamento que é pensado em si, que é consciente de suas origens e trajetórias, que é profundamente comprometido com a alteridade. O mestre ensina que não é possível ensinarmos certo, se não pensarmos certo. Não podemos ajudar uma criança a expressar os infinitos que há em si, se ainda sabemos tão pouco sobre esta lógica que herdamos e empregamos em nossas práticas, ou se ainda nem desconfiamos de suas intenções. Certamente, todas as professoras querem que as crianças aprendam, assim como querem realizar um bom trabalho pedagógico. Porém, o desejo da professora de que todas as crianças aprendam, muitas vezes é extorquido pela lógica que coloca este propósito em execução. Daí a premência por "pensar certo", por pensar o próprio pensamento.

\section{DEMARCAÇÕES ESPACIAIS: O ESPAÇO FRAGMENTADO DA ESCOLA}

Os relatos, para Certeau (1994, p. 199), poderiam ser tomados como "transporte" e nomeados como "metáforas" - o nome pelo qual os transportes coletivos são conhecidos em Atenas. Estes relatos-metáforas seriam, para Certeau, percursos que organizariam lugares, enquanto práticas do espaço. Para ele, todo relato é um relato de viagem; a linguagem metafórica seria suficiente para transpor o lugar em espaço, inserindo, ali, as "artes de dizer" de quem narra a sua história. Incluindo aquele que narra, no interior de seu próprio relato, Certeau diz que o relato não se restringe a uma simples descrição, tampouco pretende retratar algum tipo de realidade. Assim, “a história narrada cria um espaço de ficção. Ela se afasta do 'real' [...] Deste modo, precisamente, mais que descrever um 'golpe', ela o faz.” (CERTEAU, 1994, p. 153, grifo do autor). No relato, o narrador não é subordinado ao real, mas cria outras realidades ao narrar, pois adentra o quadro que configura. Sua presença inaugural ou dupla neste quadro (quando já estava e quando entra outra vez, como narrador), altera o que se conta. No relato habita o inaugural, e, com ele, a autoria. Ao narrar, o narrador não apenas descreve ou reproduz, mas cria outra coisa, e é Certeau quem, novamente, insiste em dizer que "o relato não exprime uma prática. Não se contenta em dizer um movimento. Ele o faz" (CERTEAU, 1994, p. 156, grifo do autor).

A ideia de que o relato seria tão somente a expressão verbal de uma prática é uma ideia incompleta, portanto. O relato não apenas diz; ele transporta o narrador e o ouvinte, reanima um espaço, anuncia outras práticas que não são meras cópias do 
original, mas outras, sempre. O relato não é subordinado ao original, mas é o tecelão do inaugural: em seu interior habita o conhecimento do que se passou, mas a este conhecimento acresce outras experiências, outras crenças e modos de si. Contar outra vez é dizer de novo outra coisa, fermentando as "artes de fazer" (CERTEAU, 1994). Diferente da descrição (embora a contenha), os relatos dos praticantes nutrem e mantêm vivos os espaços em que transitam, dificultando a que estes espaços sejam tomados como "lugares". Relatos transportam e modificam o que, por pressuposto, deveria ser o mesmo.

A partir da escola se desdobra, pelo mundo, o cotidiano escolar (LACERDA, 2014). Em grande parte, praticado na escola, o cotidiano escolar atravessa outros espaços sociais, tendo como meio de transporte os relatos. Estes não devem ser tomados tão somente como registros verbais, pois, como já vimos, os relatos são, também, práticas. Em se tratando da pesquisa em educação e da formação docente, o ensinamento certeauniano mostra-se como bastante relevante, uma vez que é possível a aderência à sedutora ideia de que um relato deva ser coletado, analisado e dissecado. Morto. Um relato submetido a um tratamento desta natureza, é assassinado. A partir de Certeau entendemos que o que interessa no relato não é o relato em si, mas a busca pelos sentidos postos pelo narrador. Ao relatar o narrador inscreve, a partir de uma prática, outras práticas, e é ali, no interstício "entre” estas práticas (a original e a inaugural) que reside sua astúcia, sua arte, os sentidos que tece. Trabalhar com relatos na pesquisa e na formação docente seria, então, trabalhar neste escorregadio intervalo onde o narrador empreende grande esforço intelectual na bricolagem entre o que lhe parece que foi e o que deseja que seja.

Pode soar estranha esta afirmação (quando desprovida de sua justificativa), mas os relatos não são muito importantes. Tomados isoladamente, não são importantes. Registrar e analisar o que narra uma professora sem mergulhar nas bricolagens por intermédio das quais tece sua narrativa, equivale a dissecar o morto. Mesmo correndo o risco de parecermos repetitivas, (sabemos disso, mas é que professora repete muito o que diz), é importante dizer de novo o que aprendemos com Certeau (1994, p. 156, grifo do autor), que o relato "não se contenta em dizer um movimento. Ele o faz." Um relato de uma professora é a expressão do que ela pensa sobre sua prática, e, se ao ouvi-lo, ao fundo você escuta Caetano cantando baixinho que você "não está entendendo quase nada do que eu digo", a narradora conta tudo de novo, conta outra vez para você. E outra. Conta até que o "sentido" aconteça para você (em você), pois que este "sentido" não pode ser encontrado apenas no que se diz, mas no que se cria no interior do que se faz. 
Tudo isso ajuda a compreender a linguagem metafórica que as professoras privilegiam. Diferente da linguagem conceitual que, por natureza, já carrega em si o sentido, a linguagem metafórica - os relatos - transportam o ouvinte à prática, e é neste espaço, o da prática, que devem ser rastreados os universos de sentidos. Os relatos, então, não seriam tão importantes, mas sim o "como" são ouvidos, como é percebida a tessitura de sentidos, como acontece o encontro com a narradora presente no quadro que desenha e quais saberes ela aciona, quais crenças alimenta; seu movimento, enfim.

Em Lima et al. (2015) é apresentada a diferenciação entre a normatização regulatória da cientificidade e as trajetórias indeterminadas das narrativas. Enquanto a linguagem científica percorre as prescrições que toma para si, a linguagem metafórica que tece a narrativa, coaduna com sua natureza andarilha. Assim,

Enquanto o paradigma científico moderno baseia-se na causalidade, na legalidade, na ordem e na estabilidade do mundo, de um passado que se repete previsivelmente e pode ser determinado, o modo narrativo [...] volta-se para o singular, o local, o imprevisível e o implicado. (LIMA; GERALDI; GERALDI, 2015, p. 21).

Se a estrutura da linguagem científica difere da organização não linear da linguagem narrativa, certamente hão de ser necessárias escutas distintas, também. A eminência da escuta gera expectativas em quem vai ouvir, e estas expectativas farão parte do que se ouve. O texto científico pode conduzir o leitor por meio de caminhos familiares em direção a lógicas das quais já se apropriou, mas o acesso às narrativas de professoras não prescinde de uma certa disposição por perseguir outras lógicas, revestidas como surpresas. Vamos ao segundo relato, então.

Nas escolas, na hora do recreio, a sala das professoras é o espaço onde elas se encontram para lanchar, conversar, contar casos, desabafar. Neste dia, em especial, todas que ali estavam foram silenciadas pela entrada "incomum" da professora Alice. Ela entrou falando muito alto, aparentemente nervosa. Estava indignada com a escola. Falava ininterruptamente. A princípio, ninguém entendia muito bem sobre o que ela falava, mas, quietas, todas olhavam para ela e ouviam. Ela estava indignava e dizia que era absurdo existir, na escola, um lugar específico para o aluno aprender. Segundo ela, a escola era bastante grande, com espaços diferenciados, mas que não podiam ser utilizados. O único lugar permitido para as lições era a sala de aula. Ela perguntava o motivo de haver tanto espaço na escola, se não podia ser utilizado, e contou que, ao levar sua turma para realizar uma atividade externa à sala de aula, a diretora ficou observando, sem nada dizer no momento. Na hora do café, a diretora a chamou e perguntou se a execução de seu plano de aula estava sendo cumprido, já que ela tem 
ficado muito tempo fora da sala de aula. Ao tentar explicar o que fazia com as crianças fora da sala de aula, a diretora não a ouviu; afastou-se da professora que, segundo disse, ficou sozinha, com "cara de boba".

Ninguém falou muito sobre o assunto devido ao grande nervosismo em que ela se encontrava; as falas das colegas foram mais no sentido de tentar acalmá-la e não instigar mais sua indignação, embora todas concordassem com ela e também por conhecerem seu trabalho compromissado com as crianças e sua responsabilidade com a prática pedagógica. $\mathrm{O}$ recreio terminou e cada uma voltou para o lugar demarcado que lhe cabia. No final da aula, a professora Alice tornou a conversar sobre o que havia acontecido. Ela estava mais calma, porém, não menos indignada. Ela questionava a formação da diretora, queria saber se ela não havia estudado sobre a importância da ludicidade junto às aprendizagens, queria saber se a diretora ignorava que as crianças também aprendem brincando e jogando. Em sua fala ressaltou que, aparentemente, a diretora desconhecia que os espaços da escola podem e devem ser explorados, que todos os espaços são possíveis de serem praticados. Junto a isso, denunciava uma lógica que associa a aprendizagem ao cumprimento de atividades no interior da sala de aula, como se isso fosse pré-requisito para o aprender. A professora Alice estava indignada, dizia que deveria ser respeitada, que seu trabalho era sério, que sabia o que estava fazendo quando trabalhava com as crianças fora dos limites da classe.

Alice conhecia as exigências institucionais que são impostas e, embora não as deixasse de cumprir, criou suas "táticas" (CERTEAU, 1994), que lhes permitiam burlar o instituído sem descumpri-lo, mas dando senão totalmente, pelo menos parcialmente, autoria à sua prática docente. A diretora, por sua vez, estava preocupada com as cobranças que também lhe são feitas, com resultados e mais resultados para alcançar, com metas para atingir, e que por isso quer ver todo mundo "trabalhando", produzindo resultados a qualquer preço, não queria ver ninguém ali "perdendo tempo". Naquele momento, professora e diretora observavam a mesma prática de formas distintas, assim como eram distintas também as possibilidades de dizer o que percebiam. Enquanto a diretora tinha sua voz amparada no plano institucional, havia a expectativa pelo silenciamento da professora. Esta expectativa, contudo, não se confirmou, pois que a voz da professora também foi proferida; talvez ouvida, talvez negada; mas foi dita.

Não é preciso dar voz às professoras. Professoras têm voz. Elas falam e narram suas experiências. Elas argumentam, defendem e criticam a respeito dos mais diversos tipos de questões que circulam no cotidiano escolar do qual fazem parte e, por pertencerem a este campo, falam com propriedade. Entretanto, não falam em qualquer lugar e nem com qualquer um. Elas sabem que, em muitos lugares e mo- 
mentos, é desnecessário falar, e o que aparentemente se mostra como silêncio, nada mais é do que uma rigorosa avaliação que fazem sobre a inclusão de suas falas em determinado lugar (VALLA, 1996, p. 180).

Esta rigorosa avaliação incorpora sentidos que não são conhecidos por quem ocupa um lugar de poder, e se dão a partir de uma dimensão ainda bastante desconhecida: a percepção dos praticantes. O trabalho de Valla (1996) ajuda a compreender isso, quando trata da necessidade de se compreender que os sentidos compartilhados pelos sujeitos são mediados pela experiência, e que a experiência é também uma prática política. Ignorante deste fato, o olhar hegemônico observa os movimentos dos praticantes com sua visão adulterada por seus pressupostos, depositando sua própria ignorância naquilo que vê. Assim, as narrativas docentes, mesmo fecundas, são ouvidas com condescendência, subestimadas e menorizadas no plano institucional. Sabedora disso e conhecedora do campo em que se move, a professora reserva suas narrativas para serem depositadas em terras férteis, geralmente entre seus pares. Para o observador externo, somente a ignorância e o silêncio são observáveis.

O silêncio é visível, mas não implica a inexistência da palavra. Mesmo expostas a situações onde sua verbalização é proibida, regulada ou minimizada, as professoras não se encontram desprovidas da palavra. Internamente e por meio de sua corporeidade continuam falando e narrando sua experiência e, nestes movimentos ininterruptos, inauguram conversações perceptíveis tão somente aos praticantes que tecem estes encontros. A palavra emudecida é pronunciada em outras dimensões e não perde, jamais, sua potência.

As professoras falam com seus pares, aqueles nos quais confiam e que pensam de maneira semelhante em relação às práticas docentes. Falam com aqueles com os quais formam comunidades científicas (KUHN, 2001), muitas vezes fora dos espaços escolares e, também, dentro da escola, escondidas dos dispositivos panópticos, astuciosamente, nas frestas que já bem conhecem e em outras que elas inauguram. E embora pareçam submissas ao sistema que lhe é imposto pela escola, enquanto disseminadora do todo social, a professora encarna o sujeito insubmisso de Certeau, como tática de sobrevivência no cotidiano escolar.

Escutar o que dizem as professoras, portanto, não guarda qualquer relação com o seu empoderamento ou revelação. A escuta não precisa se comprometer com o “dar a voz”, porque a voz já lhes pertence, mas em escutá-las e, talvez tão importante quanto, é o que se faz com aquilo que se escutou, com aquilo que foi posto, dito, narrado pelas professoras. Se propor a ouvir o que tem a ser dito a partir do interior da escola não deveria ser uma atribuição somente das escolas, pois estas obedecem a 
um poder ainda maior. Faz-se urgente que as políticas públicas se disponham a ouvir a voz da escola - uma voz dissipadora de verticalidades, horizontalidades e centralidades - uma voz rizomática.

\section{REGULAÇÕES TEMPORAIS: O TEMPO ACELERADO DA ESCOLA}

Histórias de escola circulam pelas escolas, pelas ruas da cidade, por vários espaços onde seja possível o encontro. O encontro é a possibilidade do relato, desta maravilhosa oportunidade de transitar novamente por espaços praticados. Em um encontro ao acaso com uma amiga professora em uma agência bancária, esta professora fez uso da ocasião e compartilhou o seu relato. Era dia de pagamento e a fila estava enorme. Se ruim por um lado, bom por outro, pois as condições tecidas aleatoriamente possibilitaram a conversa. Como é costume acontecer, a conversa caiu na escola e daí não saiu mais. Ela, refletindo sobre como as coisas mudaram na escola desde que iniciou sua carreira no início dos anos de 1990, lembrou sua postura de professora-pesquisadora, e de como isso favorecia a que ela aprendesse a ensinar junto com seus alunos. Ela contou que, em certa ocasião, trabalhara com as crianças alguns projetos que envolviam a história da arte, trazendo para a escola discussões que atravessavam a obra de pintores, escultores, músicos, compositores e tantos outros artistas. Sorrindo, dizia "nós éramos atrevidas, né?" - pois, segundo ela, não havia recursos financeiros, nem materiais didáticos, o acesso à Internet era bem restrito e, apesar de tudo isso, ela e outras professoras criavam seus projetos junto com as crianças e conseguiam realizar aquilo que idealizaram. Trabalhavam muito, desde o planejamento até a execução do projeto, mas em todo este trabalho havia alegria. Trazendo esta história guardada em sua memória, a professora observou o tempo presente, queixou-se da falta de tempo, do excesso de cobranças, das obrigações que lhes são impostas na escola, dos projetos externos que precisam executar. Em sua análise, afirmou que apesar da escola dispor de mais recursos didáticos atualmente, o sentimento que ela tem é de que as coisas pioraram.

Pensando nisso, percebemos que as instruções instituídas assoberbaram o fazer docente, comprimindo as práticas instituintes de modo que se façam timidamente. $\mathrm{O}$ excesso de regulação tem devorado o tempo que poderia ser reservado a essas práticas que traduzem experiências próprias, inaugurais. Infelizmente, a escola atual funciona na perspectiva da escola-empresa; o que sobressai nesta instituição é um saber imposto, fundado na "lógica das competências" que é inculcado nos praticantes, uma lógica que recusa a experiência e o saber que a habita; uma lógica que neutrali- 
za a história, abole as diferenças, oculta as contradições e desarma toda tentativa de interrogação (CHAUÍ, 1997). Tudo isto se manifesta claramente nas reuniões, cursos e encontros de formação de professores. As ideias hegemônicas são apresentadas em linguagem bem articulada mediante artifícios que buscam o convencimento, e esta linguagem se revela tão convincente que parece realmente inquestionável. Nestas reuniões, quem menos fala são as professoras. Elas ouvem, ouvem, ouvem, e não falam porque desistiram (lembra?). Nessa hora, apenas leem nas entrelinhas que suas experiências não são válidas. Não são consideradas legítimas.

O silêncio das professoras, em alguns espaços institucionais, não implica a inexistência da palavra. O silêncio da palavra não dispõe da capacidade de seu apagamento, pois que ela se desdobra, apesar do controle: a palavra do outro não depende de você. É verdade que a racionalidade técnica, por vezes, adentra e direciona as percepções da professora, influenciando-a de forma a olhar para seus alunos e ver "massinha de modelar". Porém, esta mesma racionalidade técnica também produz, nas professoras, outras coisas, como a indignação frente à circunscrição do espaço escolar destinado ao aprender, e a alegria por rememorar que já foram "atrevidas".

No encontro na agência bancária, e no interior de sua narrativa, a professora não apenas descrevia um quadro. Embora tenha citado os projetos que desenvolveu e registrado a diferenciação posta às condições materiais da escola em temporalidades diversas, a professora falava, também, de outras coisas. Aliás... sobre o que ela falava não sabemos, mas sabemos sobre o que ouvimos. Em sua narrativa, ouvíamos a professora dizer da velocidade vertiginosa da vida contemporânea e do nosso empobrecimento no interior do excesso. Estamos sufocando no interior do excesso. Hoje temos lápis, cadernos, computadores... temos tintas, cartolinas, livros... temos Internet, copiadoras, projetores... temos vídeos, e temos equipamentos... temos quase tudo, mas roubaram o nosso tempo.

O tempo escolar foi dividido, especificado e ocupado. As avaliações externas sussurram aos ouvidos dos currículos, e estes alojam-se nos planos de aulas, nos livros didáticos, nos cadernos de dever de casa. Ocupada com tudo isso, o que não sobra à professora é tempo. Assim como tantas outras, as narrativas da professora que estava na agência bancária, pouca gente pode ouvir, e pouca gente pode entender. Mas, mesmo assim, a vida, que rizomaticamente é responsável por tramar possibilidades para encontros e conversas, insiste. Acolhidas nestas possibilidades, as professoras narram.

No plano institucional são raras as iniciativas por se escutar e conhecer esse discurso outro, um discurso fora da ordem que lhe convém. Muito dificilmente 
se busca compreender o outro, não conseguindo se aproximar desse outro dialogicamente. Enquanto isso, as professoras falam e têm muito a dizer, mas elas já sabem onde vale a pena ou não se pronunciar. As professoras são sujeitos de sua experiência que se constitui no cotidiano escolar. São permanentemente perpassadas pelas lógicas que contribuem para tecer, reconstituindo-se permanentemente, questionando-se no interior dos conflitos que a escola e a sociedade oferecem. As professoras adentram o campo instituído e o reinventam, burlando, agindo pelas descuidadas frestas existentes em toda e qualquer estrutura para, neste espaço agora praticado, expressarem sua autoria. Astuciosamente, as professoras insistem em afirmar a legitimidade da experiência, mesmo sabedoras de que

Conhecimentos socialmente produzidos - de que o conheci-
mento chamado "científico" é apenas uma parte - têm sido des-
perdiçados ou têm circulação restrita porque são considerados
de segunda ordem. Há questões a serem sempre enfrentadas a
este respeito: como caracterizar esses dois modos de pensar?
Como pôr em relação saberes da experiência e saberes científi-
cos? (LIMA; GERALDI; GERALDI, 2015, p. 20).

Além do plano da experiência, as dimensões formativas e investigativas também podem ser favorecidas a partir da escuta das narrativas docentes. A escuta é um movimento voluntário de alteridade e não guarda qualquer relação com orelhas ou com a audição. Embora a posse de um sistema auditivo seja privilégio de muitas pessoas, ouvir não equivale a escutar. Ouvir através de ouvidos é possível a quem ouve através de ouvidos, e ouvir através de outros sentidos é possível para quem o faz, mas, o escutar nem sempre lhes ocorre. As narrativas de professoras, aparentemente descrições da prática, trazem consigo indícios de suas condições de possibilidade. Professoras não apenas lecionam para "massinhas de modelar", ou somente envolvem-se em "picuinhas" com diretoras ou somente reclamam saudosamente de suas posturas "atrevidas". Isto é o que é dito; isto é a voz; isto é o que o ouvido captura. Mas, o que dizem enquanto dizem? Quais são as “dobras” que acessamos em suas narrativas (DELEUZE, 1992)?

Enquanto o filósofo conceitualiza sobre o espaçotempo, a professora experimenta, de outras formas, sentimentos semelhantes. Enquanto o sociólogo teoriza sobre a prevalência negativa do pensamento neoliberal na educação, a professora sabe, a partir de sua prática, dos desastrosos resultados desta política em sua formação e em seu trabalho. Distraída, a professora que tem "alunos-massinha" não concebeu esta ideia, e a diretora que quer trancafiar todo mundo na sala de aula, também não sonhou com isso. Distraídas, herdaram estas ideias e, a partir delas, passaram a observar o cotidiano da escola. Concepções são tecidas na complexidade do tecido social, político, 
científico, artístico e em qualquer outra dimensão afetada pela mente humana. Elas se espalham, adentram as percepções, orientam práticas, desenham discursos. Fazem até acreditar. No interior das narrativas das professoras, habitam uns tantos desses fantasmas sem pai nem mãe, e o que espanta, é que muitas vezes elas são obrigadas a assumir a autoria do que repetiram! Veja bem, a autoria fantasmagórica é atribuída a elas, que tão somente repetiram.

Bourdieu rejeita a idéia de que o fenômeno social é unicamente
produto das ações individuais, e que a lógica dessas ações deve
ser procurada na racionalidade dos atores. Ele pensa que a for-
mação das idéias é tributária das suas condições de produção.
Que os atos e os pensamentos dos agentes se dão sob "cons-
trangimentos estruturais". Por isso insiste que, na pesquisa, se
mantenha uma "vigilância epistemológica": o cuidado perma-
nente com as condições e os limites da validade de técnicas e
conceitos. (THIRY-CHERQUES, 2006, p. 30).

O trabalho com narrativas de professoras não se restringe a organizar uma situação ótima para sua ocorrência, registrá-las em áudio, transcrever e ler. É preciso um trabalho gigante, um esforço epistemológico de quem escuta, um arregaçar as mangas na tentativa de entender que a professora não é a única habitante de sua própria narrativa. Quantas influências existem ali! Quantos fragmentos de orientações "científicas" forjam os termos que ela emprega! Quantos reducionismos e armadilhas para o pensamento ela é levada a consumir! Precisamos encontrar a professora no interior de suas próprias narrativas, pois ela deve estar ali, em algum lugar, amordaçada por este turbilhão de "discursos competentes" (CHAUÍ, 1997).

\section{A PALAVRA DA PROFESSORA NÃO DEPENDE DE VOCÊ}

A partir de conversas com professoras, iniciamos este artigo buscando refletir, também como professoras, sobre concepções que tecem as práticas docentes e como estas alimentam suas narrativas. Durante o trabalho, nos propusemos a uma "vigilância epistemológica" relacionada à escuta do que diziam as professoras, afinal, os padrões que ordenam os fios que as tecem também nos perpassam, somos também receptoras desta herança que nos forma.

Trouxemos a metáfora da bailarina que nos possibilitou conversações e olhares distintos, como a diferença e recursividade entre descrição e relato, e o estranhamento quando percebemos que aquelas bailarinas olhavam para os próprios pés. A bailarina que fala por meio de seu corpo ajuda-nos a entender que a fala não é privilégio da voz, e isso remete às professoras que também não falam apenas 
por intermédio de suas vozes, mas pelos gestos, olhares e também quando silenciam. Praticantes do cotidiano, elas sabem que suas falas, muitas vezes subestimadas, como se fossem teoricamente esvaziadas, as escondem e revelam nos espaços controlados pelo outro. Discutimos isso a partir das histórias de escola que trouxemos para o texto, dialogando com alguns autores que nos ajudaram a entender um pouco mais esse vasto cotidiano. Certeau (1994) nos ajudou a pensar sobre os relatos, revelando que o que foi contado pelas professoras configura-se como outra prática, visto que ao relato primeiro são acrescidas outras nuances de sua experiência.

Os relatos das professoras promovem a fascinante proeza de espalhar o cotidiano escolar pelo mundo, rompendo com os limites dos muros escolares. O que interessa, neste acontecimento não é o relato propriamente dito, mas a busca de sentidos postos por quem narra. Feito artesãs interessadas em trabalhos de bricolagens, as professoras compartilham entre si suas narrativas, pois já entenderam, há tempos, que ouvidos externos as escutam como se falassem uma língua estrangeira.

Os sentidos existentes na linguagem metafórica, tão usada pelas professoras, às vezes, traduzem-se em silêncio. Silêncio que revela a avaliação das professoras sobre sua fala em determinado lugar; silêncio que revela a percepção das praticantes. O silêncio não implica a inexistência da fala. Apesar das práticas instituídas sobrecarregarem as práticas docentes, sua ocorrência é insuficiente para eliminar as práticas instituintes. Estas acontecem mais timidamente, apesar da lógica de escola-empresa que habita o sistema escolar na atualidade.

No interior das narrativas, encontramos professoras escondidas sob esse turbilhão de regulações que adentraram o espaço escolar, mas que, felizmente, não dispõem de forças bastantes para subtrair a autoria docente. As professoras têm andado atarefadas com o cumprimento de novos "afazeres" que penetram seu trabalho. Estes "afazeres" lhes são endereçados por meio de inovações curriculares, da avaliação externa, da formação continuada e de diferentes ordenações do espaçotempo escolar. São "afazeres", palavra cujo significado o dicionário registra como sendo "acostumar, adaptar; ocupação, tarefa" - entre outros termos que, relacionados, configuram o projeto de se ocupar fartamente alguém com algo que não lhe interesse, até que este algo se torne, para este alguém, o substituto de suas próprias ideias.

As bailarinas de Degas olham atonitamente para os pés; já perceberam onde, exatamente, depositam-se as marcas da técnica que exaustivamente repetem. São marcas visíveis no corpo, um corpo que fala o que faz, que mostra aquilo em que foi transformado. Em alguns momentos, encontramos nas professoras outras marcas, também filhas da técnica, do contexto político, social, econômico, científico. Por ve- 
zes presentes em seus gestos, em suas vozes, em seus olhares, estas marcas afetam sua corporeidade e percepção.

As marcas do instituído insistem em adentrar seu universo e perturbar sua percepção, afetando a prática e desdobrando-se em narrativas. Estas marcas - orientações cuja origem é externa - em grande parte não são observáveis para as próprias professoras. Por vezes, produzem nelas a ideia de "crianças-massinha", ao mesmo tempo que dificultam a que as professoras se ouçam a si, e se pensem a si. Em outros momentos, a regulação fermenta a indignação até que esta jorre, favorecendo a que as professoras compartilhem entre si seu espanto diante da esquizofrênica demarcação do espaço escolar, ou seu posicionamento crítico frente às mudanças políticas e sociais que afetam o cotidiano da escola. No conflituoso e permanente embate entre diferentes orientações, as professoras tecem narrativas que reanimam suas práticas, fazendo dos relatos o meio de transporte para viajarem até si mesmas.

Para finalizar, trazemos um pequeno texto escrito pela querida professora Dora, que foi impresso em um dos boletins do Grupo de Pesquisas de Professoras de Escolas do qual ela fazia parte, e distribuído pelas escolas de seu município há aproximadamente doze anos. Com o texto da Dora nos despedimos, e com o texto da Dora sonhamos uma outra educação. O título do texto, Sonho.

Sai do encontro do dia 16 de dezembro, como sempre, com a cabeça rodando mais que máquina de lavar. Pensava em toda a discussão sobre individualidade, diversidade, emancipação, regulação. Será que temos que ser padrão? Será que temos que seguir o rumo "natural" ditado pela sociedade? Será que nosso destino está traçado por normas impostas por aqueles que recebem autorização para mandar/ditar/outorgar? Acabei sentindo uma ponta de inveja dos hippies, do rock metal, dos piercing, ou melhor resumindo, de todos os que um dia ousaram e ousam burlar as "leis". Sonho, palavra que talvez não tenha muito significado em uma sociedade que procura padronizar individuos, estabelecendo normas e regras de procedimentos. Tentam criar um caminho no qual todos devem percorrer; mas os sonhos são constitutivos dos indivíduos, são alimentados por paixões, e paixão é um sentimento impetuoso, de dificil controle. Sonhos adormecem, mas não morrem. Portanto, sonhar é nos encontrar, é buscar nossa essência, nossa individualidade. No dia 11 de dezembro de 2002, quatro alunos que tive durante este ano receberam o diploma da quarta série (trabalho com Educação de Jovens e Adultos). A alegria e satisfação de receber um documento almejado, tão sonhado, estão registradas nas fotografias e na filmagem. Momento de interseção entre sonhos e regras (a regra diz que temos que estudar e ter diplomas). Ai eu me pergunto: o que fez e faz estas pessoas saírem de seus lares, na busca de um banco escolar, após um dia exaustivo de trabalho, sendo que a regra é sentar e assistir às novelas e aos telejornais, reclamar do 
patrão, do salário e do serviço que está por fazer? Acredito que a resposta seja a confiança que temos em nossos sonhos. Sonhos que renascem numa pequena fresta, em qualquer estação, sempre que são fomentados pelos individuos. Sonhos como os que sonharam meus alunos: um operário que está com a pagamento dos salários em atraso, que quer continuar na quinta série com o filho mais velho; sonho de uma costureira que quer estudar até se formar na faculdade; sonho de uma avó que adora os livros, principalmente Machado de Assis, que quer ver suas netinhas com a diploma na mão; sonho de uma moça que quer ver um Brasil melhor, sem racismo e preconceito. Sonhos que começaram a virar realidade porque acreditaram que a vida pode ser diferente mesmo quando os primeiros momentos não foram favoráveis. Sonhos que não foram barrados pelos fuxicos dos vizinhos, pelas palavras desanimadoras dos pessimistas, pelo cansaço ou pelo estresse da professora. Sonhos que estimularam a fugir à regra, a ser uma bela e honrosa exceção. Quando entramos em uma sala de aula temos que atender às regras de procedimentos da escola e do sistema educacional. Como atendê-las, sendo que cada indivíduo é um campo cheio de sonhos, os mais diversos, os mais intimos? E unir a este universo de sonhos, os nossos próprios? E, como contribuir no desempenho de nosso oficio para sermos semeadoras de sonhos e nunca motosserras? (BOLETIM GOPPE, Profa. Maria Auxiliadora Ribeiro dos Santos, 2003).

Nota explicativa:

${ }^{1}$ Este trabalho se inscreve desde a influência dos estudos em Cotidianos, o qual não é tomado como lugar, mas como espaçotempo praticado (v. Michel de Certeau). Sendo assim, os achados de pesquisa não são frutos de prescrições metodológicas que circunscrevem o espaço e definem os sujeitos a serem investigados, mas de uma abertura das pesquisadoras por aprender no interior deste campo. Para maior conhecimento sobre a pertinência do acaso em processos investigativos, remetemos o (a) leitor (a) aos referenciais que tratem das implicações filosóficas da física no início do século XX (v. Boaventura de Sousa Santos).

\section{REFERÊNCIAS}

BOLETIM GOPPE. Boletim do Grupo de Pesquisas de Professoras de Escolas. Carangola, n. 1, mar. 2003. Mimeografado.

CERTEAU, M. de. A invenção do cotidiano. Artes de fazer. Petrópolis: Vozes, 1994.

CHAUÍ, M. Cultura e democracia. São Paulo: Cortez, 1997.

DELEUZE, G. Sobre Leibniz. In: DELEUZE, G. Conversações. São Paulo: Ed. 34, 1992.

FOUCAULT, M. Vigiar e punir. Petrópolis: Vozes, 1987. 
FREIRE, P. Pedagogia da autonomia. São Paulo: Paz e Terra, 1997.

KUHN, T. S. A Estrutura das Revoluções Científicas. São Paulo: Perspectiva, 2001.

LACERDA, M. P. de. A professora e o cotidiano da cidade pequena. Niterói: EdUFF, 2014.

LIMA, M. E. C. de C.; GERALDI, C. M. G.; GERALDI, J. W. O trabalho com narrativas na investigação em educação. Educação em Revista, Belo Horizonte, v. 31, n. 1, p. 17-44, jan./mar. 2015.

THIRY-CHERQUES, H. R. Pierre Bourdieu: a teoria na prática. RAP, Rio de Janeiro, v. 40 n. 1, p. 27-55, jan./fev. 2006.

VALLA, V. V. A crise de interpretação é nossa: procurando compreender a fala das classes subalternas. Educação \& Realidade, v. 21, n. 2, p. 177-190, jul./dez. 1996.

Recebido em: 10 de setembro de 2015

Aceito em: 01 de fevereiro de 2016

Endereço para correspondência: Avenida João Jasbick, s/n, Bairro Aeroporto, 28.470-000, Santo Antônio de Pádua, Rio de Janeiro, Brasil; mitsipinheiro@id.uff. br; annetehosken@yahoo.com.br 
